\title{
Effect of Pruning Severity on Yield, Drying Time and Wages in Flame Seedless Dry-on-vine and Traditional Raisin Production Systems in Argentina
}

\author{
R.S. Espíndola*, J.A. Camargo, E. Pringles, M. Battistella \\ INTA, EEA San Juan, AER Caucete, UNSJ FI, Rivadavia, 340 Caucete, Argentina
}

Submitted for publication: February 2017

Accepted for publication: September 2017

Keywords: Dry on vine, raisins, flame seedless, labour, distribution buds

\begin{abstract}
Raisin grapes are potentially more profitable than wine grapes in San Juan, Argentina, although the traditional system of grape drying requires an extensive use of costly labour. Production costs might be reduced by adopting the dry-on-vine (DOV) raisin-making system, but the feasibility of DOV in Argentina has not been assessed, and neither have the costs and pruning schemes. Thus we determined drying time and yields, estimated wages per hectare, and determined the influence of pruning severity on Flame Seedless raisin grapes. A completely random design with six treatments and six replicates was used in the 2013 to 2016 seasons. The treatments comprised differences in the nodes per cane, nodes per vine, distribution of nodes, and sugar content. Descriptive statistics and variance analysis were calculated for fresh fruit weight, dry fruit weight, drying ratio and drying time. The leaf area and its relationship with dried fruit weight also were calculated. These data were processed with the Infostat program. The DOV system demands between 11 and 31 additional days during the drying period and reduces labour costs by between $38 \%$ and $64 \%$ compared to the traditional system. Long pruning with the same load of buds is better. Furthermore, the DOV system is not associated with a lower production and thus appears to be a financially sustainable alternative to traditional production systems for Flame Seedless raisin grape producers in Argentina.
\end{abstract}

\section{INTRODUCTION}

The most important varieties used for raisin grape production in Argentina are Flame Seedless, Arizul or INTA 351, Sultanina and Sugraone (Doreste, 2011; INV, 2016) More than $80 \%$ of the nation's raisin production (4 274 ha) is in San Juan Province (INV, 2015). All of these grapevines are cultivated in parallel trellis systems which are $2.1 \mathrm{~m}$ in height. Each plant was tied to cross the main wires and were supported with two secondary wires. Four main cordons arise from the trunk, which are subject to Guyot pruning (spur and cane) (Pugliese \& Espíndola, 2011). The drying season begins at the end of January and finishes at the beginning of April.

In the traditional drying method, the clusters are hand harvested, packed into boxes, transported to a drying yard, spread on plastic nets atop cobblestones, and left to dry (Pangavhane \& Sawheny, 2000). They are put on plastic nets located on plots covered with stones, called ripieras, which should slope down to allow maximum water runoff in the case of rain (Doreste, 2011). Pugliese and Espíndola (2012) determined that, between the years 2006 and 2009, 15 to 23 days were required for the drying of the Sugraone, Sultanina and Flame Seedless varieties, with the weather being the factor that determines this variation. Because the grapes are dried on the ground, small stones, leaves, dust and other undesirable matter can accumulate in the raisins, and such matter may be difficult or expensive to eliminate (Jairaj et al., 2009).

The DOV system, introduced in 1956, is an alternative method for the commercial production of sun-dried raisins (Whiting, 1992). In contrast to traditional systems, DOV raisins are dried on the trellised vines (Espíndola et al., 2012). This system requires significant changes in pruning, plant management and fruit handling (Fidelibus, 2007). Fruiting canes should be cut near their base to ensure that cane cutting causes most clusters on the vine to commence drying (Whiting, 1992). Also, in varieties like Fiesta and Selma Pete, cane severance at more than $19^{\circ}$ Brix is associate with greater raisin yields ( $\mathrm{kg} / \mathrm{vine}$ ) than vines whose canes are severed with less soluble solids (Parpinello et al., 2012).

However, some raisin varieties, such as Flame Seedless, are more fruitful at their basal buds than Sultanina (Pugliese \& Espíndola, 2011), which increases the risk of undried clusters even when canes are severed near their base. After the cane severance, a 50\% active leaf area should

*Corresponding author: E-mail address: espindola.rodrigo@inta.gob.ar

Acknowledgements: The authors wish to thank Matthew Fidelibus and Jaclyn Stogbauer, for their assistance 
be maintained to keep up the vigour of the plant (Whiting, 1992). Severance is done by hand, with a work performance of approximately 0.4 ha per person per day (Whiting, 1992). At present in San Juan, some raisin producers using the traditional system are faced with insufficient labour (Battistella \& Novello, 2013), and the available labour is expensive (Bas, 2006; Dominguez, 2006; Espíndola et al., 2012). The new technology requires more skilled workers (Radonich et al., 1999), which means higher production costs (Espíndola et al., 2014). In Sugraone, the DOV system reduced labour costs by $40 \%$ without affecting yields, but also extended the drying period by 20 to 53 days (Espíndola et al., 2014).

This paper postulates that the DOV parallel system will not affect the yield or leaf area in the following seasons because of different levels of load and different node distributions, and will reduce labour associated with the drying process. The objectives of this research were i) to evaluate raisin yield in terms of node distribution for different pruning systems (nodes/vine and nodes/cane); ii) to measure the raisin yields (kg/vine), drying ratio, drying time (days) and leaf area $\left(\mathrm{cm}^{2}\right)$ before cane severance in the DOV system compared to a traditional system of drying grapes with different sugar contents; and iii) to estimate the wages needed for the two raisin-production systems.

\section{MATERIALS AND METHODS}

The study took place in Zonda, San Juan Province, which is $30 \mathrm{~km}$ from San Juan city. The area has a soil with medium texture and is deep, without any depth impediments. The study was carried out on own-rooted Vitis vinifera cv. Flame Seedless grapevines on a parral trellis system with a planting frame of 3 x 2 (1 666 plants/ha) with drip irrigation. The irrigation plan was based on reference evapotranspiration (ET) provided by a nearby weather station and a crop coefficient $\left(\mathrm{K}_{\mathrm{c}}\right)$ from INTA technicians (Liotta \& Sarasua, 2013). The fertilisation plan was based on replacing the amount of nitrogen estimated to have been removed from the vineyard in the previous harvest. A completely randomised design with six treatments and six replicates was used, with the experimental unit being one plant (36 plants in total).

Moisture content (\%), fresh weight $(\mathrm{kg})$, dry weight $(\mathrm{kg})$, drying ratio (raisin weight obtained from a given amount of fresh grape) (Christensen \& Peacock, 2000), drying time (days between cane severance and raisin harvest), time of work execution ( $\mathrm{min} /$ worker) and leaf area $\left(\mathrm{cm}^{2}\right)$ were determined for all treatments. The Infostat program (version 2016, Universidad Nacional de Córdoba, Argentina) was used and an analysis of descriptive statistics and ANOVA was performed. Descriptive methods and data tables were used for the analysis of time. Season 2013/2014 was studied in node number (from 80 to 140 node/plan) and node distribution (from 8 to 20 nodes/cane) as follows: control (Parral system and traditional production, 16 canes (C) 6 nodes/C +10 spurs -136 buds/vine); DOV 6C long (20 nodes/C +10 spurs -140 buds/vine); DOV $6 \mathrm{C}$ short (15 nodes $/ \mathrm{C}+10$ spurs -110 buds-vine); DOV 6C shortest $(10$ nodes/C +10 spurs -80 buds/vine); DOV 10C (12 nodes/C +10 spurs -140 buds/vine); and DOV $15 \mathrm{C}$ ( 8 nodes $/ \mathrm{C}+$ 10 spurs -140 buds/vine). Season 2015/2016 was studied according to node distribution (from 10 to 20 nodes/cane) and sugar content (from 20 to $22^{\circ}$ Brix at the time of severance of the canes), as follows: control (Parral system and traditional production, 16 canes (C) 6 nodes $/ \mathrm{C}+10$ spurs $\left.-20^{\circ} \mathrm{Brix}\right)$; DOV $5 \mathrm{C}$ less sugar (20 nodes $/ \mathrm{C}+10$ spurs $\left.-20^{\circ} \mathrm{Brix}\right)$; DOV $5 \mathrm{C}$ more sugar $\left(20\right.$ nodes $/ \mathrm{C}+10$ spurs $\left.-22^{\circ} \mathrm{Brix}\right)$; DOV $8 \mathrm{C}$ less sugar $\left(12\right.$ nodes $/ \mathrm{C}+10$ spurs $\left.-20^{\circ} \mathrm{Brix}\right)$; DOV $8 \mathrm{C}$ more sugar $\left(12\right.$ nodes $/ \mathrm{C}+10$ spurs $-22^{\circ}$ Brix $)$; and DOV $10 \mathrm{C}(10$ nodes $/ \mathrm{C}+10$ spurs $-20^{\circ}$ Brix).

After $15^{\circ}$ Brix, sugar content was measured every three days with a refractometer using 12 berries for each quarter plant. When the average clusters assigned reached $20^{\circ}$ Brix, canes on the vines of that treatment were cut by hand with shears. Canes were cut at the base, leaving one or two nodes. We kept measuring sugar content until $22^{\circ}$ Brix, when the rest of the canes of those vines were cut. The control was harvested by hand. Clusters of hand-harvested grapes (Control) were packed into lugs, transported to a drying yard, placed on plastic nets, and laid on the gravel-coated surface to dry. After seven days the grapes were turned and, after 10 days, a sample was taken for a moisture percentage calculation in the laboratory using electrical conductivity with a Dried Fruit Moisture Tester (DFA, UC Berkeley California $\mathrm{N}^{\circ}$ AIII6). Raisin DOV samples were also taken each week and the date of DOV raisin harvesting and of traditional raisin harvesting was estimated when the moisture average reach $15 \%$.

The calibration of the measurement foliar area method was carried out taking the length of 30 shoots: $80 \%$ from canes and $20 \%$ of spurs before summer severance. The CI-203 CID leaf area meter laser owned by EEA San Juan INTA was use for this measurement. Then a regression equation was obtained. Subsequently, in each season, before severance of the canes, the length of eight shoots per plant was measured and the number of shoots per plant was counted. The relationship between shoot length and leaf area was used to estimate the leaf area for each treatment at the same time.

The fresh weight was estimated by counting the number of clusters per plant and the average weight of 50 clusters from 50 vines around the treatments on the day the canes were cut. The raisin yield per hectare was estimated using the average weight per treatment multiplied by the number of vines.

\section{RESULTS}

During the 2013/2014 season, raisin weight differed significantly (Table 1) among treatments, with vines having eight nodes/cane (DOV 15C) producing the lowest raisin weights, and vines with 12 to 20 nodes/cane producing the most raisins. Vines subjected to traditional raisin-making practices produced a similar number of raisins as those assigned to DOV 15C. However, in the following season, $2015 / 2016$, vines with a similar number of nodes produced similar yields, regardless of the distribution of the nodes and differences in sugar content.

In the 2013/2014 season, the variable drying ratio showed a low coefficient of variation $(8.48 \%)$ and a level of significance lower than 0.0001 . The greatest differences for the variable were observed between the treatments with 
20 nodes/cane (DOV 6C long, lowest drying ratio) and eight nodes/cane (DOC 15C, highest drying ratio) (Table 2). The Control had a drying ratio higher than treatments DOV 6C long, DOV 6C short, DOV 6C shortest and DOV 10C, and lower than DOV 15C. In the 2015/2016 season, with no load changes, no significant differences in treatments were observed.

In the 2013/2014 season, traditional drying (Control) occurred in 20 days. The vines with the DOV system (DOV $6 \mathrm{C}$ to DOV 15C) required 31 days to reach the same level of moisture content (14\% to $16 \%)$. This implies that plant drying required 11 days more drying, therefore a time ratio of $35.5 \%$ higher than the control. However, in the 2015/2016 season, all DOV treatments took 51 to 56 days to dry, which means 31 to 36 days longer than the traditional method. In the $2015 / 2016$ season, a $2^{\circ}$ Brix difference between vines from 20 nodes/cane to 10 nodes/cane (DOV 5C less sugar and more sugar/DOV $8 \mathrm{C}$ less sugar and more sugar/DOV 10C) at cane cutting (20-22 ${ }^{\circ}$ Brix) did not show a difference in yield. The treatments with $20^{\circ}$ Brix were harvested five days before treatment with $22^{\circ}$ Brix.

In the 2013/2014 season, the traditional system (Control) required more man hours to prepare and collect the raisins than the DOV systems due to the extra harvesting, laying, turning and lifting operations. The time required for the treatment with 20 nodes/cane (DOV 6C long) was 35\% lower than the time involved with respect to the traditional drying system. In the treatment with 10 nodes/cane (DOV 6C shortest), the time taken was 58\% less than the time taken by the traditional system. In the 2015/2016 season, the wages in percentages indicate that the DOV systems generated savings of more than $60 \%$ (Fig. 1) with respect to the traditional system.

Shoot leaf area ranged from $1216.4 \mathrm{~cm}^{2}$ to $8662.3 \mathrm{~cm}^{2}$, with an average of $3316.53 \mathrm{~cm}^{2}$. The equation used is leaf area $=-385.53+16.68 *$ length, with an accuracy of $91 \%$. The leaf area before cane severance (after a cane severance season) did not show any significant differences between treatments in the seasons 2013/2014 and 2015/2016.

When analysing the leaf areas of the vines undergoing the traditional drying system and the DOV system with different nodes/vine (2013/2014) and node distribution (2015/2016), no significant differences were observed between treatments. When calculating a quotient between the variables leaf area $\left(\mathrm{cm}^{2}\right)$ and raisin weight (g) (Table 3), it was observed that DOV 5C differed from plants with 10 nodes/cane (DOV 10C) $(2015 / 2016)$, which indicates a lower yield in relation to its own leaf area.

\section{DISCUSSION}

Parpinello et al. (2012) studied the DOV system in Fiesta and Selma Pete with produce yield (kg/vine) at $20^{\circ}$ Brix to $22^{\circ}$ Brix of $1.96 \mathrm{~kg}$ to $10.01 \mathrm{~kg}$ (2006 to 2008). The current study shows that the DOV system in Flame Seedless produced between $5.01 \mathrm{~kg} /$ vine and $12.87 \mathrm{~kg} / \mathrm{vine}$ (2014 to 2016). The traditional system produced a lower yield (4.44 to $7.33 \mathrm{~kg} / \mathrm{vine}$ ). Also, Parpinello et al. (2012) showed that, for the Fiesta and Selma Pete varieties, there were no differences in yield $(\mathrm{kg} /$ vine $)$ with differences of $1^{\circ}$ Brix or $2^{\circ}$ Brix at cane severance. In the current study, Flame Seedless showed

TABLE 1

Raisin weight (kg/vine) as a function of nodes/vine and nodes/cane; season 2013/2014

\begin{tabular}{|c|c|c|c|c|c|}
\hline Treatments & Average (kg/vine) & $\mathrm{n}$ & & & \\
\hline 5 & 5.01 & 6 & $\mathrm{~A}$ & & \\
\hline 0 & 7.33 & 6 & $\mathrm{~A}$ & $\mathrm{~B}$ & \\
\hline 4 & 8.39 & 6 & & $\mathrm{~B}$ & \\
\hline 3 & 12.41 & 6 & & & $\mathrm{C}$ \\
\hline 2 & 12.59 & 6 & & & $\mathrm{C}$ \\
\hline
\end{tabular}

Test: LSD Fisher Alfa: $=0.05$; DMS: $=2.48930$

TABLE 2

Drying ratio of Flame Seedless grapes subjected to nodes/vine and nodes/cane; season 2013/2014

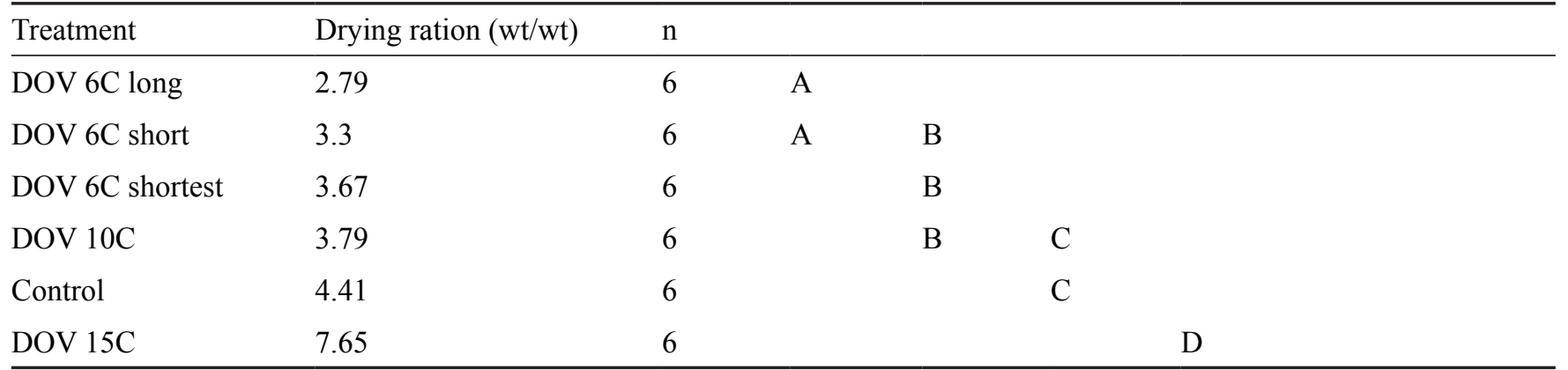

Test: LSD Fisher Alfa: $=0.05$; DMS: $=2.48930$ 


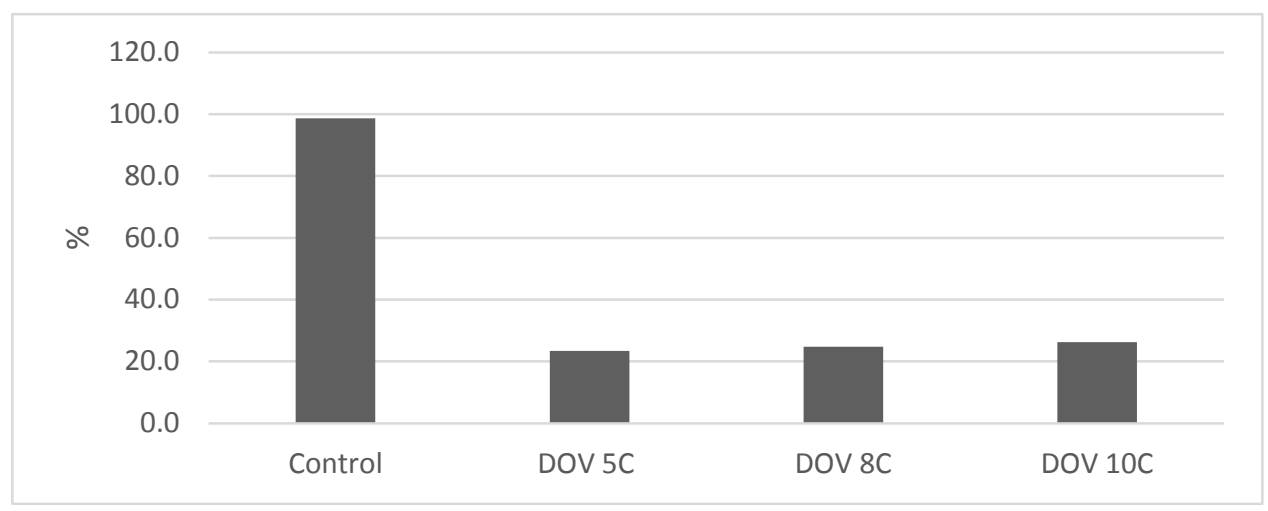

FIGURE 1

Times recorded for each treatment (laying, turning and lifting), as percentages; season 2015/2016.

TABLE 3

Analysis of the variance (SC type III) for variable leaf area/raisin weight ( $\mathrm{cm}^{2} / \mathrm{g}$ ); season 2015/2016

\begin{tabular}{lllll}
\hline Treatment & Average & $\mathrm{n}$ & & \\
\hline DOV 5C less sugar & 10.77 & 3 & A & \\
DOV 5C more sugar & 15.67 & 3 & A & B \\
DOV 8C more sugar & 20.09 & 3 & A & B \\
Control & 26.3 & 3 & A & B \\
DOV 8C less sugar & 27.52 & 3 & A & B \\
DOV 10C less sugar & 28.93 & 3 & & B \\
\hline
\end{tabular}

Test: LSD Fisher Alfa: $=0.05 ;$ DMS: $=2.48930$

no differences in yield ( $\mathrm{kg} / \mathrm{vine})$ with a $2^{\circ}$ Brix difference between treatments in the 2015/2016 season.

On the other hand, other research has shown that a reduction in the leaf area during harvest time due to cane cutting can subsequently affect vine growth and return yields (Kliewer \& Fuller, 1973; Kingston \& Van Epenhuijsen, 1989) by up to $50 \%$. The current paper demonstrates that, after three seasons of application of the DOV system, severance at the base of the cane and an estimated $50 \%$ reduction in leaf area did not generate problems in yields.

The fruit load on the vine changes the relationship between leaves and fruit. The literature cites values ranging from 5 to $15 \mathrm{~cm}^{2} / \mathrm{g}$ of fruit, according to variety (Winkler, 1958; Kliewer, 1970; Kliewer \& Ough, 1970; Kaps \& Cahoon, 1992). In this work, leaf area per gram of fruit varied from $2.25 \mathrm{~cm}^{2} / \mathrm{g}$ to $8.17 \mathrm{~cm}^{2} / \mathrm{g}$. The lowest relationship is associate with DOV with fewer canes/vine and more nodes/ cane duo to a relatively major raisin weight $(\mathrm{g})$ for the same leaf area $\left(\mathrm{cm}^{2}\right)$.

Williams et al. (1987) found that defoliation in summer had no influence on fruitfulness in the next season when leaves were removed from the canopy. Kliewer and Antcliff (1970) report that defoliation at later stages does not give rise to significant yield reductions in the following season. Nevertheless, Scholefield et al. (1977) suggest that cane severance can reduce yields if less than $50 \%$ of leaf area is removed. The current study corroborates that, in the DOV system, yields between seasons 2013/2014 and 2015/2016 were not affected when defoliation occurred in summer when the grapes were ripe.

According to Vila et al. (2010), fresh pulp cells represent $80 \%$ to $90 \%$ of the grape's weight. In addition, Smart (1992) states that $95 \%$ of the weight loss in the drying process is water. The influence of these factors in the drying ratio is $4 \mathrm{~kg}$ of fresh grapes for $1 \mathrm{~kg}$ of raisins (Doreste, 2011). The results obtained indicate that, in order to obtain $1 \mathrm{~kg}$ of raisins, an average of $4.32 \mathrm{~kg}$ of fresh grapes is needed when grapes are at 20 to $22^{\circ}$ Brix. On the other hand, Pangavhane and Sawheny (2000) argue that the drying time in the traditional system (without discrimination of variety) is eight to 10 days. Doreste (2011) emphasises that in the varieties with small berries, the drying may be completed in 10 days, whereas varieties with larger berries may require 12 to 19 days to dry (Pugliese \& Espindola, 2011). In this paper, for the Flame Seedless variety, drying with the traditional system took 20 days in 2014. Sugraone DOV raisins can take up to 52 days to dry (Espíndola et al., 2014) because of differences in the weather and berry composition. In this sense, the Flame Seedless variety was dried in 31 days with DOV in 2014, and in 51 days in 2016, with a drying period of 11 and 31 days longer than with the traditional system. Keller (2003) and Smart (1992) state that if a vine is severely pruned it will have less capacity for growth and fruiting. It has also been observed that the DOV system is linked to risks 
regarding lower yield and a reduction in leaf area (Espíndola et al., 2014). In this work, it was observed that the DOV system produced a higher yield than the traditional system when pruned with long canes (up to six canes of 20 nodes each).

According to Bendini et al. (1999), the change in labour demand showed seasonal differences (Battistella \& Novello 2013). Radonich et al. (1999) suggest that if workers receive government subsidies it is a disincentive to productivity, but better-skilled workers may demand higher wages, leading to an increase in production cost (Espíndola et al., 2014). The current study determined that the DOV system requires less labour than the traditional raisin-production method and, consequently, reduces production costs. Dominguez (2006) indicates that labour is an expensive resource, and that to maintain profitability it is necessary to reduce labour costs. Espindola et al. (2014) determined that labour accounts for $67.8 \%$ to $85.6 \%$ of the raisin-production costs in Argentina, and is thus by far the most expensive aspect (Pangavhane \& Sawheny, 2000; Battistella \& Novello, 2013). This study shows that, with the DOV system, there is a decrease in wages of $40 \%$ to $60 \%$. Thus Whiting (1992), Fidelibus et al. (2008) and Espíndola et al. (2014) agree that the DOV system is more economically sustainable because it reduces costs.

\section{CONCLUSIONS}

The DOV system is an alternative to improve the profitability of raisin-production systems. Grape growers have the option of drying grapes on their property on ground that can be used for other productive purposes. The traditional drying system has the advantage of achieving a shorter drying time than the DOV system, which means less exposure of the grapes to possible inclement weather. The application of DOV does not diminish yields when vines are pruned to long canes, even with fewer nodes. The distribution of the nodes has a greater influence on yield than the number of nodes per vine, except when there is poor pruning. The DOV system generates up to $64 \%$ savings in labour compared to the traditional system. This justifies its use in situations of low labour availability or high labour costs.

The interpretation of the results is that different nodes/ vine and node distribution derived from the application of the system do not lead to a weakening of the plant caused by a lower leaf area. After three seasons of cane severance in Flame Seedless vines, there was no decrease in the leaf area achieved by cane cutting, or in productivity. A change in the node distribution influences the yield, being it being greater with fewer canes and more nodes.

\section{LITERATURE CITED}

Bas. F. (2009) Capacitación efectiva. Recursos humanos en la Agricultura. Trabajo con la mano de obra. Revista Agronomía y Forestal UC. 29. p. 8.

Battistella, M. \& Novello, R., 2013. Impacto de los métodos de cosecha asistida sobre la productividad de la mano de obra en la vendimia de uva para vino y mosto. Ruralis $17,4-8$.

Battistella, M. \& Novello, R. 2013. Impacto de los métodos de cosecha asistida sobre la productividad de la mano de obra en la vendimia. Ruralis V 17, 4-8.
Bendini, M., Radonich, M. \& Steimbreger, N., 1999. Historia de la vulnerabilidad social de los golondrinas en la cuenca frutícola del rio negro. In: La Colmena (Ed.). De golondrínas y otros migrantes, Buenos Aires. pp. 32-52.

Christensen, P. \& Peacock, W., 2000. Harvesting and handling. In Christensen, P. (ed.). Raisin production manual. ANR University of California, California. pp. 193 - 206.

Dominguez, J., 2006. Crecimiento, desarrollo y recursos humanos. Agronomía y forestal 29(2), 5 .

Doreste, P., 2011. Pasas de uva. Alimentos Argentinos 41-45.

Espíndola, R., Ferreyra, M., Pringles, E. \& Battistella, M., 2014. Análisis fisiológico de la aplicación del sistema de secado de uvas en parrales con ahorro de jornales en cosecha. RIA 40(3), 276-281.

Espíndola, R., Pugliese, F. \& Battistella, M., 2012. Productividad de la mano de obra en la obtención de uva de mesa. Estudios Rurales 2(3), 24.

Fidelibus, M., 2007. Development of new raisin production systems. I Simposio Internacional de uva de mesa y pasas. 13-15 of September, 2007, San Juan, Argentina. pp. $57-64$.

Fidelibus, M., Christensen, P., Katayama, D. \& Ramming, D., 2008. Early ripening grapevine cultivars for dry-on-vine raisins on an open gable trellis. Hort. Technol. 18(4), 740-745.

INV, 2015. Superficie con viñedos según destino de la uva. Instituto Nacional de Vitivinicultura, San Juan.

INV, 2016. Superficie de viñedos provincia de San Juan. Total por departamento. Mendoza: Instituto Nacional de Vitivinicultura.

Jairaj, K., Singh, S. \& Srikant, K., 2009. A review of solar dryers developed for grape drying. Sol. Energy 83(9), 1698-1712.

Kaps, M. \& Cahoon, G., 1992. Growth and fruiting of container-grown Seyval blanc grapevines modified by changes in crop level, leaf number and position, and light exposure. Am. J. Enol. Vitic. 43, 191-199.

Keller, M. 2003. Grapevine anatomy and physiology. Irrigated Agriculture Research and Extension Center, Washington State University.

Kingston, C. \& Van Epenhuijsen, C., 1989. Influence of leaf area on fruit development and quality of Italia glasshouse table grapes. Am. J. Enol. Vitic. $40,130-134$.

Kliewer, W., 1970. Effect of time and severity of defoliation on growth and composition of "Thompson Seedless" grapes. Am. J. Enol. Vitic. 21, 37-47.

Kliewer, W. \& Antcliff, A., 1970. Influence of defoliation, leaf darkening, and cluster shading on the growth and composition of Sultana grapes. Am. J. Enol. Vitic. 2, 26-36.

Kliewer, W. \& Fuller, R., 1973. Effect of time and severity of defoliation on growth of roots, trunk, and shoots of Thompson Seedless grapevines. Am. J. Enol. Vitic. 24, 59-64.

Kliewer, W. \& Ough, C., 1970. The effect of leaf area and crop level on the concentration of amino, acids and total nitrogen in 'Thompson Seedless' grapes. Vitis 9, 196-206.

Liotta, M. \& Sarasua, A., 2013. Programación del riego en vid para varoedades de esa y pasa con riego presurizado. Segunda Reunión Internacional del Riego 152-165.

Pangavhane, D., Sawhney, R., \& Sarsavadia, P. 1999. Effect of various dipping pretreatment on drying kinetics of Thompson seedless grapes. Journal of Food Engineering (39), 212-216.

Pangavhane D R \& Sawhney R L, Review of research and development work on solar driers for grape drying, Energy Convs Manage, 43 (2002) 45-61. 
Parpinello, G., Heymann, H., Vasquez, S., Cathline, K. \& Fidelibus, M., 2012. Grape maturity, yield, quality, sensory properties and consumer acceptance of Fiesta and Selma Pete dry on vine raisins. Am. J. Enol. Vitic. 63(2), 212-219.

Pugliese, F. \& Espíndola, R., 2011. Aptitud de Pasificación de distintos cultivares apirénicos. Simposio Internacional de uva de mesa y pasas. 15-17 of September, San Juan Argentina. 111-116.

Radonich, M., Steimbreger, N. \& Ozino Caligaris, M., 1999. Cosechando temporadas. In De golondrinas y otros migrantes. La Colmena Editorial, Buenos Aires. pp. $53-58$.

Scholefield, P., Neales, T. \& May, P., 1978. Carbon balance of the Sultane vine (Vitis vinifera L.) and the effect of autumn defoliation by harvest pruning. Aust. J. Plant Physiol. 5, 561-570.
Smart, R., 1992. Canopy management. In: Coombe, B.G. \& Dry, P.R. (eds). Viticulture, vol 2: Practices. Winetitles, Adelaide. pp. 85 - 101.

Vila, H., Paladino, S., Nazrala, J. \& Lucero, C., 2010. La uva, su desarrollo y composición. In Manual de calidad de uva. Ediciones INTA, pp. 85 - 101.

Whiting, J., 1992. Harvesting and drying of grapes. In: Coombe, B.G. \& Dry, P.R. (eds). Viticulture. Winetitles, Adelaide. pp. 328 - 359.

Williams, L. E; Biscay, P. J; Smith, R. J. 1987. Effect of interior canopy defoliation on berry composition and potassium distribution in Thompson Seedless grapevines. Am. J. Enol. Vitic. 38, 287-292. 